\title{
Recent advances in the management of peptic ulcer bleeding
}

\section{[version 1; peer review: 2 approved]}

\author{
Ian Beales (iD)
}

Department of Gastroenterology, Norfolk and Norwich University Hospital, Norwich, UK

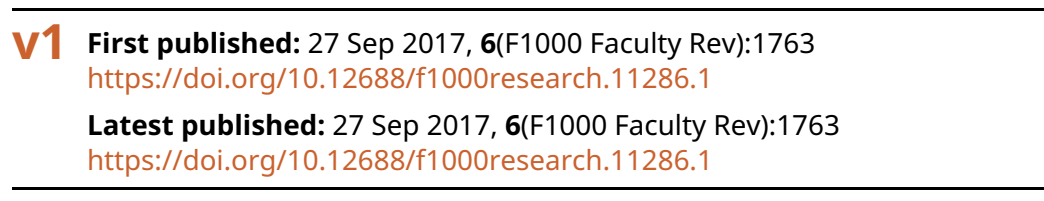

\section{Abstract}

Acute upper gastrointestinal haemorrhage due to peptic ulcer bleeding remains an important cause of emergency presentation and hospital admission. Despite advances in many aspects of management, peptic ulcer bleeding is still associated with significant morbidity, mortality, and healthcare costs. Comprehensive international guidelines have been published, but advances as well as controversies continue to evolve. Important recent advances include the evidence supporting a more restrictive transfusion strategy aiming for a target haemoglobin of 70-90 g/l. Comparative studies have confirmed that the Glasgow-Blatchford score remains the most useful score for predicting the need for intervention as well as for identifying the lowest-risk patients suitable for outpatient management. New scores, including the AIMS65 and Progetto Nazionale Emorragia Digestiva score, may be more accurate in predicting mortality. Pre-endoscopy erythromycin appears to improve outcomes and is probably underused. High-dose oral proton pump inhibition (PPI) for 11 days after PPI infusion is advantageous in those with a Rockall score of 6 or more. Oral is as effective as parenteral iron at restoring haemoglobin levels after a peptic ulcer bleed and both are superior to placebo in this respect. Within endoscopic techniques, haemostatic powders and over-the-scope clips can be used when other methods have failed. A disposable Doppler probe appears to provide more accurate determination of both rebleeding risk and the success of endoscopic therapy than purely visual guidance. NonHelicobacter pylori, non-aspirin/non-steroidal anti-inflammatory drug ulcers contribute an increasing percentage of bleeding peptic ulcers and are associated with a poor prognosis and high rebleeding rate. The optimal management of these ulcers remains to be determined.

\section{Keywords}

gastrointestinal hemorrhage, peptic ulcer hemorrhage, endoscopic hemostasis, $\mathrm{H}$ pylori, anticoagulant drugs, non-steroidal antiinflammatory drugs

\section{Open Peer Review}

Approval Status

Approval Status

\section{version 1}

27 Sep 2017

Faculty Reviews are review articles written by the prestigious Members of Faculty Opinions. The articles are commissioned and peer reviewed before publication to ensure that the final, published version is comprehensive and accessible. The reviewers who approved the final version are listed with their names and affiliations.

1. David M Jensen, David Geffen School of Medicine at UCLA, Los Angeles, USA

2. Grigorios I Leontiadis, McMaster University, Hamilton, Canada

Any comments on the article can be found at the end of the article. 
Corresponding author: Ian Beales (i.beales@uea.ac.uk)

Competing interests: The author declares that he has no competing interests.

Grant information: The author(s) declared that no grants were involved in supporting this work.

Copyright: @ 2017 Beales I. This is an open access article distributed under the terms of the Creative Commons Attribution License, which permits unrestricted use, distribution, and reproduction in any medium, provided the original work is properly cited.

How to cite this article: Beales I. Recent advances in the management of peptic ulcer bleeding [version 1; peer review: 2 approved] F1000Research 2017, 6(F1000 Faculty Rev):1763 https://doi.org/10.12688/f1000research.11286.1

First published: 27 Sep 2017, 6(F1000 Faculty Rev):1763 https://doi.org/10.12688/f1000research.11286.1 


\section{Introduction}

Acute upper gastrointestinal (GI) haemorrhage remains an important clinical problem. The incidence of non-variceal acute upper GI bleeding in the UK is approximately 85 per 100,000 per year $^{1}$. Although the specific mortality associated with acute variceal bleeding is higher ${ }^{2}$, peptic ulcer bleeding (PUB) remains the commonest cause of acute GI bleeding overall and significant bleeding requiring transfusion ${ }^{2,3}$. Despite considerable advances in many aspects of the management of PUB, the overall mortality remains significant (approximately 10\%), the increasing age and comorbidity of the patients somewhat offsetting the therapeutic advances.

There are several evidence-based guidelines to aid the management of PUB $^{4,5}$, although comprehensive audits have shown that all aspects of management do not always reliably follow guidelines $^{3}$. New information is continually becoming available in all aspects of PUB, and in many cases these have not had time to directly inform guideline development. In this review, important recent developments in all aspects of managing PUB are discussed and relevant controversies placed into context to aid the practical management of ulcer bleeding.

The management of ulcer bleeding can be divided for convenience into areas of recognition, risk assessment, resuscitation, endoscopic and salvage therapies, and drug therapies in both the peri-bleeding and post-bleeding situations.

\section{Recognition}

Usually the presentation of acute upper GI bleeding is obvious to the clinician, certainly once the presence of blood in the vomitus or melaena passed rectally is detected. One significant dilemma remains over the likely site of bleeding for profuse, haemodynamically significant fresh rectal bleeding. Is this from a colonic source or very rapid transit from an upper GI source? This has implications for the investigative process. In the United Kingdom, nationwide review of severe GI bleeding, general clinical features, and suspicion in this situation were poorly correlated with the actual site of bleeding ${ }^{3}$. The presence of a pulse rate greater than the systolic blood pressure was associated with an upper GI source for fresh rectal bleeding ${ }^{3}$, and although further studies examining this index in a prospective way are required, it certainly seems reasonable to perform a gastroscopy initially before lower GI endoscopy in these patients showing that degree of circulatory compromise after appropriate resuscitation.

\section{Resuscitation}

Despite the high prevalence of PUB, there are few data on any specifics of fluid resuscitation in this context. The general clinical principles on restoring circulating fluid volume and adequacy of organ perfusion are employed, although it seems inevitable that there will be individual choice in terms of fluids used and rate given. Obviously, randomised studies in this area are extremely difficult to do and hence the widely cited trial examining blood transfusion strategies was extremely welcome ${ }^{6}$, although the limitations inherent in recruiting into such a trial in acute bleeding must always be considered when reviewing the results. In common with an increasing body of data from other critically ill patients, across the spectrum of medicine including major sepsis ${ }^{7,8}$, a restrictive blood transfusion strategy seems at least as good as a more traditional liberal strategy. In the key trial ${ }^{6}$, the strategy of a single unit as required, and repeated as necessary, with a transfusion trigger of $70 \mathrm{~g} / \mathrm{l}$ to maintain the haemoglobin at 70-90 g/l was as safe and effective as a more traditional haemoglobin target of 90-110 g/l. The trial recruited all comers with upper GI bleeding and was not specifically designed to look at subgroups. Overall mortality was lower in the restrictive transfusion group (5\% versus $9 \%$ ). Those with variceal bleeding or Child's A or B cirrhosis particularly seemed to benefit from the conservative transfusion strategy with improved mortality and rebleeding rates. In those with PUB, there was less difference between the two strategies, although all important clinical outcomes favoured the restrictive strategy (mortality 3\% versus 5\%, rebleeding $10 \%$ versus $17 \%$, and surgery $2 \%$ versus $6 \%$ ). Recruitment to the trial was rather selective, excluding those with very severe bleeding and significant circulatory diseases, which may limit generalisation. Data published only in abstract form ${ }^{9}$ examining real-world outcomes after transfusion for PUB suggested a contrary finding and showed an association between more units transfused and lower death rates.

A meta-analysis pooled the results from the four available studies of transfusion strategies in acute upper GI bleeding, although all have different methodologies and inclusion criteria ${ }^{10}$. Not all of these included studies specifically examined only acutely bleeding peptic ulceration. Again, results favoured a restrictive strategy: there were significant reductions in death and length of stay with the restrictive strategy. Rebleeding rates were also non-significantly lower in the restrictive group (odds ratio $0.26,95 \%$ confidence interval [CI] 0.03-2.10). An even more recent meta-analysis including only data on acute GI bleeding from five randomised controlled trials showed that a restrictive transfusion strategy was associated with lower all-cause mortality (relative risk 0.65 , 95\% CI 0.44-0.97) and rebleeding (relative risk 0.58 , 95\% CI $0.40-0.84$ ) without any effect on ischaemic events ${ }^{11}$. The exact optimal resuscitation strategy is unclear and always needs to be individualised to the specific patient. However, given the consistency and biological plausibility of the results and the costs and potential harm of blood transfusion, it would seem prudent to employ a conservative transfusion strategy for most patients with PUB, whilst maintaining adequate circulating fluid volumes.

It is important to stress that transfusion strategies are but one part of fluid resuscitation in PUB and that in the acutely bleeding patient haemoglobin levels form only one part of the assessment of cardiovascular instability and that decisions on fluid and blood replacement must be governed by the need to restore adequate organ perfusion. However, it does seem that crystalloid fluid resuscitation followed by blood to maintain the haemoglobin level at $70-90 \mathrm{~g} / \mathrm{l}$ is most appropriate for most patients; further data are required for those with severe or critical vascular and circulatory diseases.

\section{Risk stratification}

There are many systems that have been used to stratify risks in upper GI bleeding. Probably the two most widely used and studied 
are the Rockall scores (both pre- and post-endoscopy) and the Glasgow-Blatchford score $(\mathrm{GBS})^{12}$. Although these have always been designed to assess somewhat different aspects, there continue to be studies comparing the clinical utility of these studies. It must be remembered that the Rockall scores assess mortality risk but were never designed directly as decision tools (accepting that the risk assessment of the patient clearly does inform clinical decision-making indirectly) but that the GBS was explicitly designed and validated to predict those cases not needing intervention (therapeutic endoscopy or blood transfusion). Thus, not surprisingly, the GBS consistently performs better in identifying lower-risk cases, suitable for direct discharge and outpatient management ${ }^{13,14}$. Further recent international validation of the GBS has confirmed that a score of 0 or 1 is associated with a very low risk of intervention and that hospital admission and emergency endoscopy are not required ${ }^{15}$.

Further scores have been proposed. The AIMS65 score has been advocated as an even simpler score requiring scoring only on a 5-point score for each of the following factors: albumin of less than $30 \mathrm{~g} / \mathrm{l}$, international normalised ratio (>1.5), Glasgow coma scale score of less than 14 , systolic blood pressure of less than $90 \mathrm{mmHg}$, and age of more than 65. Although the AIMS65 can reliably predict mortality, it appears less accurate than the GBS in determining the need for interventions such as blood transfusion or admission to critical care ${ }^{15,16}$.

A further score, the Progetto Nazionale Emorragia Digestiva (PNED) score system, which relies on a rather complex multipart scoring using age, presence of cancer, renal failure, American Society of Anaesthesiologists grade, cirrhosis, rebleeding, and failure of endoscopic therapy, has been proposed. A large prospective study of over 3,000 patients confirmed that the GBS clearly performed best in identifying the lowest-risk patients and also in predicting interventions such as blood transfusion or endoscopic therapy. Although the PNED and AIMS65 scores were best at predicting mortality, none of the scores apart from the GBS appeared to be clinically useful in determining either the safety of outpatient management or the need for endoscopic therapy ${ }^{15}$. A GBS of 7 or more was best at predicting the need for endoscopic treatment ${ }^{15}$.

A further score based on seven factors-systolic blood pressure of less than $100 \mathrm{mmHg}$, syncope, haematemesis, haemoglobin of less than $100 \mathrm{~g} / \mathrm{l}$, blood urea of $22.4 \mathrm{mg} / \mathrm{dl}$, estimated glomerular filtration rate of less than $60 \mathrm{~mL} / \mathrm{min}$ per $1.73 \mathrm{~m}^{2}$, and the use of anti-platelet medications-was recently proposed ${ }^{17}$. This score was superior to the pre-endoscopy Rockall and AIMS65 scores in predicting clinical intervention in a cohort of Japanese patients ${ }^{17}$ but has not been compared against the GBS or evaluated more widely.

Timing of emergency endoscopy in acute upper GI bleeding remains a controversial area, and although immediate endoscopy (as early as possible) seems theoretically attractive, this has not been supported by evidence. Studies have shown that very early endoscopy is not associated with better outcomes and in some cases is associated with worse outcomes (although this latter effect could have been an artefact of the design of the observational studies) ${ }^{18,19}$. More recently, those patients with a GBS of 12 or more were shown (again in an observational study) to have lower mortality with a presentation to endoscopy time of more than 13 hours, whereas those with lower GBSs did not seem to benefit from such early endoscopy ${ }^{20}$. This suggests that GBSs can be used both to triage patients not needing admission and to detect those who may benefit from relatively early endoscopy.

Further modifications of the GBS have also been reported, removing the most subjective of the criteria and relying merely on measurable haemodynamics and laboratory values, omitting the scoring for chronic disease/major comorbidities, melaena, and syncope. Interestingly, the abbreviated score seemed to perform as well as the full GBS and was again superior to the Rockall scores at predicting the need for clinical intervention ${ }^{21}$. Whilst further validation studies are required, this may prove to be a useful modification in clinical practice.

\section{Endoscopy and endoscopic therapy}

Dual therapy, that is adrenaline/epinephrine infiltration plus either thermal coagulation with a bipolar probe or mechanical haemostasis with endoclips, remains the optimal endoscopic therapy advocated in major guidelines ${ }^{4,5}$. However, the thermal or mechanical aspects are the most important, and although adrenaline is often used to clear the endoscopic field, it probably adds little to the haemostasis as secured by these other means ${ }^{12}$. Although there are a variety of through-the-scope endoscopic clips available, there are no data showing clear superiority of any one type.

Within endoscopy, there are three important recent developments: Doppler probe-guided lesion assessment and treatment, large over-the-scope clips, and haemostatic powders. The exact place of all of these within the management pathway requires further assessment, but all seem to offer some advantages in certain circumstances.

Doppler probe assessment to detect significant arterial signals in the ulcer base had been reported many years previously ${ }^{22}$. However, the lack of availability of the equipment and lack of convincing evidence of efficacy at the time rather precluded further adoption. More recently, there has been an increase in interest, stimulated by the availability of an easier-to-use Doppler unit and disposable, relatively low-cost endoscopic probes (Vascular Technologies Inc., Nashua, NH, USA). Two studies from the same group have shown initially how Doppler probe assessment is more accurate than classic endoscopic scoring at predicting rebleeding risks ${ }^{23}$ and secondly, in a randomised trial, that Doppler probe-guided management reduces rebleeding and further intervention compared with standard treatment ${ }^{24}$. Doppler assessment showed that many oozing ulcers (Forrest $1 \mathrm{~b}$ ) are actually not associated with significant arterial flow into the ulcer (only $46.7 \%$ showed a positive Doppler signal) and that these ulcers are associated with a lower rebleeding rate than typically assumed. The rate of Doppler-positive arterial flow in oozing ulcers is actually significantly lower than the prevalence of positive Doppler signals for active arterial bleeding (100\%), non-bleeding visible vessel (Forrest 2a, 90.7\%), and those with adherent clot (Forrest 2b, $68.4 \%$ ). Interestingly, $40.5 \%$ of ulcers with flat haem spots alone 
(Forrest 2c), which are classically associated with a low risk of rebleeding, had a positive arterial Doppler signal, whilst in clean-based ulcers (Forrest 3 ) only $8.3 \%$ had a positive Doppler signal. Repeating Doppler assessment post-standard endoscopic treatment showed a considerable reduction in arterial flow, and persistent arterial inflow was associated with an increased risk of rebleeding ${ }^{23}$.

A subsequent randomised trial compared the use of the Doppler probe to inform both the indication for therapy and the success of that therapy against standard haemostatic treatment based purely on endoscopic visualisation ${ }^{24}$. Endoscopic therapy was applied on the basis of the presence of a Doppler signal rather than endoscopic appearance, and after endoscopic therapy, the ulcer was re-interrogated and retreated if an arterial signal was still present. The Doppler probe allows clearer localisation of the feeding artery. Overall, Doppler use in this manner was associated with a significant reduction in rebleeding. Rates of rebleeding at 30 days were $8 / 72(11.1 \%)$ in the Doppler-treated group and 20/76 (26.3\%) in the standard care group. Residual arterial signal despite maximal endoscopic therapy (adrenaline, bipolar probe, through-the-scope clips) was strongly associated with rebleeding (8/9 cases, $88.9 \%)$ compared with $0 / 8(0 \%)$ of those who had continued endoscopic retreatment until the Doppler signal was obliterated.

This technique looks very promising. The application of the Doppler probe allows more accurate definition of the rebleeding risk of ulcers (superior to standard endoscopic stigmata), facilitates tracing of the underlying artery for direction of haemostatic methods, and allows post-treatment interrogation to define the efficacy of endoscopic therapy. Further studies in other populations with less experienced and committed operators are required before widespread adoption, and further data on the efficacy of this advance are awaited with interest.

These data with the Doppler probe showing that oozing ulcers (Forrest 1b) are associated with significantly lower risks of rebleeding post-endoscopic therapy ${ }^{23,24}$ are in keeping with a retrospective analysis of data from one of the large studies of proton pump inhibitor (PPI) therapy after endoscopic therapy ${ }^{25}$. In the placebo-treated group, rebleeding was much lower in those with oozing ulcers $(4.9 \%)$ than in those with spurting (Forrest 1a, $22.5 \%$ ), adherent clot (Forrest 2b, 17.6\%), and visible vessel (Forrest 2a, 11.3\%). It was previously thought that as oozing ulcers were seen to be 'actively bleeding' that these were high-risk lesions. These recent data confirm that Forrest $1 \mathrm{~b}$ lesions tend to have smaller feeding arteries and hence rebleeding rates are lower than previously believed. Interestingly, this study also showed that intravenous esomeprazole did not reduce the already-low postendoscopic rebleeding rate in the oozing ulcers (in comparison with the other high-risk stigmata), suggesting that parenteral acid suppression may be withheld from this group after successful haemostasis and standard oral therapy used ${ }^{25}$. This reappraisal of rebleeding rates associated with classic endoscopic stigmata of recent haemorrhage has important implications for the interpretation of existing studies and the design of future studies as grouping all active bleeding groups (Forrest 1a and 1b) together now seems inappropriate given the clearly divergent rebleeding risks.

The main limitations of typical endoscopic clips are their relatively small size and the pressure that the jaw can apply to close tissue or provide mechanical haemostasis. The much larger and stronger over-the-scope endoscopic clip (OTSC, Ovesco Endoscopy, Tubingen, Germany) overcomes many of these drawbacks, being able to grasp larger and more fibrotic areas than standard clips and to apply more pressure onto feeding arteries. The obvious cost of this is having to preload the clip on the endoscope before intubation and much greater unit cost and sometimes difficulty passing the clip through the upper oesophageal sphincter. The OTSC clip is US Food and Drug Administration (FDA)-approved and available in many areas, being utilised to close fistulas and perforations in addition to acute PUB. Several case series have reported successful haemostasis with this device when other endoscopic methods have failed. Honegger et al. ${ }^{26}$ reported $85 \%$ success in treating PUB (28/35), although in a smaller case series, haemostatic success was reported in only $4 / 7$ cases of refractory bleeding peptic ulcer ${ }^{27}$. The OTSC clip has also been used successfully as primary treatment for PUB: Manno et al. reported $100 \%$ success in 21 cases $^{28}$. There are no randomised or indeed comparative studies available at present, but as a second-line endoscopic technique these clips seem to provide a further useful tool.

Haemostatic powders are in a similar position. These seem to be a promising technology but are not yet supported by comprehensive randomised trial data. There are now several powders commercially promoted in various geographical locations, the first being Hemospray (Cook Medical, Bloomington, IN, USA) but others are now available, although they are not yet FDA-approved for use in the USA. These are proprietary mineral preparations that, when sprayed onto a bleeding area through a cannula inserted through the channel of an endoscope, provoke rapid haemostasis. The powder acts as both a physical barrier upon contact with moisture and a powerful procoagulant by concentrating clotting factors at the site of application. Again, there are no randomised trials, but several case series showing successful haemostasis after failure of first-line endoscopic therapies show that this technique can also be usefully employed in the most difficult refractory bleeding ulcers. In a comprehensive literature review of reported cases, Hemospray was successful in $88 \%$ of 81 cases of bleeding peptic ulcers ${ }^{29}$. Obviously, this method provides no destruction of the underlying artery (as clips or bipolar probes do), and the rate of rebleeding and the subsequent natural history of PUB bleeding in this manner are unknown. Haemostatic powders do not influence the underlying arterial inflow, and at present it is unclear whether rebleeding rates with highest-risk stigmata (spurting arteries or those with significant positive Doppler traces) are clinically problematical. The powder application invariably obscures the endoscopic view, and perhaps repeat second-look endoscopy will be required to perform more secure haemostasis. At present, this cannot be regarded as a routine first-line therapy but in some cases can be extremely useful when other methods have failed. The technique is relatively easy, although care must be taken to avoid 
premature exposure of the powder to liquid, which activates the powder. In the author's experience, applying this in a duodenal cap with a rapidly bleeding artery is often quite difficult but can be applied for bleeding lesions when other methods are technically impossible or have failed and may provide rescue haemostasis in those cases. It is important to note that the requirement for blood or liquid for effective activation often precludes the use of haemostatic powders on non-bleeding but protuberant arteries (Forrest 2a lesions) that do merit some form of endoscopic therapy. Further data reporting the different haemostatic powders in relation to more standard haemostatic methods and in ulcers with different bleeding stigmata will help refine the place of the powders in management.

\section{Drug therapy}

Pre-endoscopy PPI infusion is recommended by some guidelines but not by all ${ }^{12}$. Although this seems to downstage the endoscopic appearance of bleeding ulcers, the effect on hard clinical end-points such as rebleeding or hospital stay is debateable.

Post-endoscopy PPI treatment after endoscopic therapy to high-risk ulcers has repeatedly been shown to be better than placebo at reducing rebleeding and surgery ${ }^{30}$. However, despite a multitude of studies, the optimal regimen is unclear. Many clinicians use the original 'Hong Kong' regimen (bolus followed by continuous infusion of omeprazole, pantoprazole, or esomeprazole) for 72 hours. Other dose regimens, including intermittent parenteral dosing and even high-dose oral PPI, have also been shown to be effective, and it is not clear what the optimal regimen is ${ }^{31,32}$. As previously discussed, the rebleeding rate after successful endoscopic haemostasis in oozing (Forrest 1b) ulcers is low and does not seem to be reduced by parenteral high-dose acid suppression and hence treatment may be rationalised in those patients to standard oral PPI therapy ${ }^{25}$.

After endoscopic therapy and 72 hours intravenous PPI, high-dose oral acid suppression seems to be beneficial for highest-risk patients. Cheng et al..$^{33}$ reported that 11 days of double-dose oral esomeprazole (40 mg twice daily) in this context was superior to oncedaily esomeprazole $40 \mathrm{mg}$ (with $40 \mathrm{mg}$ once daily subsequently for both groups) in preventing rebleeding (10.8\% versus $28.7 \%$ in the 4-28 days post-index bleed) in patients with a full Rockall score of 6 or more. There was no significant difference in mortality, hospital stay, or blood transfused. Thus, there is a rationale for treating the higher-risk patients (Rockall score of 6 or more) with higher-dose PPI for the period after initial stabilisation.

There is a sound rationale for using prokinetics before endoscopy in upper GI bleeding to clear the stomach and improve both the endoscopic views and probably safety. Individual trials have shown inconsistent results, but recent meta-analyses showed that intravenous erythromycin before endoscopy was associated with meaningful clinical benefit in terms of improved mucosal visualisation, reduction in repeat endoscopy, and blood transfused as well as length of stay but that metoclopramide was less effective $e^{34-36}$. Erythromycin is probably underused and seems to be a simple intervention that would improve outcomes.
The management of concurrent anticoagulation is an increasing problem for those involved in the care of acute PUB. The use of prothrombin complex concentrate to reverse the anticoagulation effects of vitamin $\mathrm{K}$ antagonists (VKAs) such as warfarin is well established $^{12}$. The direct-acting oral anticoagulants (DOACs), the thrombin antagonist dabigatran, and the factor $\mathrm{X}$ inhibitors apixaban, rivaroxaban, and edoxaban present more of a problem. Although the anticoagulation effect declines relatively rapidly because of renal clearance, life-threatening bleeding will require reversal in some patients. The first specific reversal agent for dabigatran has just been licenced and, though expensive, should be available to treat significant dabigatran-associated PUB. Idarucizumab is a monoclonal antibody against dabigatran and will not reverse the other DOACs ${ }^{37,38}$. There are relatively few data on treatment of upper GI bleeding associated with these agents, although widespread use of tranexamic acid is not routinely indicated in PUB $^{39}$ (although the results of the large worldwide HALTIT trial are awaited with interest ${ }^{40}$ ); in this particular situation, the use of tranexamic acid seems reasonable ${ }^{41}$. Prothrombin complex concentrate seems to reverse the anticoagulation effect of factor $\mathrm{X}$ inhibitors in healthy volunteers and should probably be considered in severe life-threatening bleeding, although there are really no data specifically showing an effect in $\mathrm{PUB}^{42}$. A specific antidote to factor Xa inhibition has been shown to rapidly reverse the anticoagulant effect and hopefully will be available for clinical use soon ${ }^{43}$.

Acute upper GI bleeding is a significant drain on the iron stores of the body, and many patients are anaemic after initial management. A randomised trial compared subsequent management strategies in this group in non-variceal upper GI bleeding (mostly peptic ulcer-related). Iron therapy-either a one-off dose of ferric carboxymaltose or oral ferrous sulphate $200 \mathrm{mg}$ daily-was more effective than placebo at restoring haemoglobin levels to normal. After 12 weeks, $70 \%$ of placebo-treated and $17 \%$ of iron-treated patients were still anaemic ${ }^{44}$. There was no difference in the rates of improvement in anaemia between parenteral and enteral iron groups, although higher ferritin levels were seen in the parenteral group ${ }^{44}$. There was no significant toxicity, and it seems logical that supplemental iron therapy should be used in those patients with anaemia at the cessation of the peptic ulcer bleed.

\section{Management of refractory bleeding}

Despite advances in endoscopic and pharmacological therapies, a significant minority of patients experience significant rebleeding. Surgery has traditionally been regarded as the appropriate approach. Increasingly, interventional radiology is regarded as the initial therapeutic approach before surgery. There are no randomised trials to guide therapy, nor are there likely to be. Though not supported by trial data, the author's own practice is to place endoclips to mark the site of bleeding in those deemed at highest risk of needing embolization (most obviously in those with failed endoscopic haemostasis but also in those with technically difficult but successful haemostasis) to facilitate subsequent radiological localisation.

A number of case series have reported high technical success and acceptable complication rates with radiological embolization for 
acute $\mathrm{PUB}^{45-47}$, and it is believed that overall the safety of interventional radiological embolization is significantly better than surgery and hence most guidelines now advocate radiological embolization as the rescue therapy of choice. However, not all studies agree: single-centre observational studies and a meta-analysis have suggested that rates of rebleeding are higher following embolization and mortality rates equivalent ${ }^{48,49}$. All such studies are somewhat difficult to interpret because of case mix: patients undergoing embolization tended to be older and have more comorbidities.

\section{Follow-up and prevention}

An understanding of the major causes of PUB naturally leads to developing strategies for both primary and secondary prevention. The major ameliorable causes of PUB are Helicobacter pylori and drugs, although it is important to note the apparent rise in idiopathic-non- $H$. pylori, non-aspirin/non-steroidal antiinflammatory drug (NSAID)—ulcers.

Strategies to deal with $H$. pylori need to encompass both the declining efficacy of eradication therapies and the poor sensitivity of $H$. pylori testing in the context of $\mathrm{PUB}^{50}$. Empirical eradication at the presentation with bleeding has been advocated in areas with a high prevalence of $H$. pylori, whilst an alternative approach of careful follow-up testing and focused treatment may be more applicable in areas with a low prevalence of $H$. pyloriinduced ulcers ${ }^{51}$. In any case, $H$. pylori eradication regimes must be effective in the population being treated and 14-day courses of four agents (either bismuth-containing or not) are now standard in Europe and the USA, although 7-day clarithromycincontaining regimens are still used in the UK in areas with a known low prevalence of clarithromycin-resistant $H$. pylori (for a full review of $H$. pylori eradication strategies, see the Maastricht $\mathrm{V}$ guidelines ${ }^{52}$ ). It is essential that all those treating H. pylori are alert to the efficacy of their current treatment regimens and follow up patients assiduously.

For many years, it has been established that the sensitivity of all endoscopy-based $H$. pylori tests is lower in acute $\mathrm{PUB}^{50}$. The reasons for this are unclear and are not as simple as being affected by blood in the lumen. The yield of biopsy-based tests can be significantly improved by taking additional biopsies from the gastric body ${ }^{50}$, but owing to a residual false-negative rate, careful follow-up testing may still be more appropriate in those initially negative ${ }^{51}$. In the acute bleeding setting, ${ }^{13} \mathrm{C}$ urea breath testing on return from endoscopy seems to be the most accurate test for $H$. pylori but many units find this logistically difficult to $\operatorname{organise}^{50}$. In contrast, the faecal antigen test has a high falsepositive rate in acute PUB, possibly due to cross-reaction with blood components in the GI lumen, and cannot be recommended for $H$. pylori testing in the acute setting ${ }^{50}$. The diagnostic yield for $H$. pylori in the context of PUB can be significantly enhanced by performing diagnostic testing at least 4 weeks after the index bleed $^{53}$.

Although aspirin and other anti-platelet agents are clearly associated with an increased risk of PUB, in many cases these agents are indicated because of the underlying vascular disease, and it is now accepted that where indicated aspirin should be continued (or interrupted for a minimal interval of fewer than 3 days) in acute $\mathrm{PUB}^{51}$. A small risk in early rebleeding is more than offset by a significantly reduced risk of vascular events and death. This approach is supported by data from both a relatively small clinical trial and observational follow-up data ${ }^{54,55}$.

The most appropriate treatment after an aspirin-induced bleed is aspirin plus a $\mathrm{PPI}^{56}$; this is superior to the $\mathrm{P}_{2} \mathrm{Y}_{12}$ antagonist clopidogrel alone as secondary treatment. There are fewer data on the newer $\mathrm{P}_{2} \mathrm{Y}_{12}$ antagonists ticagrelor and prasugrel, but these are more potent anti-platelet agents, and not surprisingly the risk of GI bleeding seems to be higher than aspirin or clopidogrel ${ }^{57,58}$. Patients with drug-eluting coronary artery stents do need to continue dual anti-platelet therapy for a year; PPI co-treatment reduces bleeding in those taking aspirin plus clopidogrel ${ }^{59}$. The relative benefits and risks of aspirin plus PPI versus clopidogrel plus PPI after an aspirin-induced PUB are unclear. Observational data suggest that aspirin is safer, more effective, and preferable ${ }^{60,61}$. An interesting effect of the increased use of gastro-protection with anti-platelet agents is that as the incidence of upper GI bleeding has decreased, the incidence of lower GI bleeding has remained stable, such that in patients taking dual anti-platelet agents with PPI cover, the risk of lower GI bleeding is now approximately three times higher than that of upper GI bleeding ${ }^{62}$.

In general, PPI co-treatment has been advocated with aspirin for primary and secondary prevention ${ }^{51}$, although a recent study looking at secondary prevention in a Chinese population showed that famotidine was equivalent to rabeprazole ${ }^{63}$. Previous data suggested that PPI treatment was better ${ }^{64}$, and until more data in wider populations are available, PPI treatment remains the treatment of choice.

Similar to the case with anti-platelet agents, it is now becoming apparent that where indicated early resumption of anticoagulation for atrial fibrillation after a PUB is beneficial; again, a risk of rebleeding is more than offset by reductions in stroke and death. The exact optimal time for reintroduction of anticoagulation after a PUB is unclear; leaving reintroduction for 3 months imposes an excessive risk of thrombotic events ${ }^{65,66}$, whilst very early reintroduction does increase the rebleeding risk, and the compromise of reintroduction after 7-15 days seems to provide the optimal reduction in thromboembolic events compared with rebleeding ${ }^{67,68}$. More studies specifically examining this effect are required.

Previous studies have confirmed that selective COX-2 inhibitors are safer than traditional non-selective NSAIDs in terms of GI complications $^{51}$. The combination of celecoxib plus a PPI is associated with the lowest risk of rebleeding after an NSAIDinduced PUB, when reintroduction of anti-inflammatory therapy is required ${ }^{51}$. However, concerns about the cardiovascular safety of COX-2 inhibitors led to many clinicians being reluctant to prescribe these. More recent data suggest that the increased cardiovascular risk is common to all cyclo-oxygenase inhibitors, and a large randomised study powered to look at cardiovascular rather than GI outcomes showed no inferiority of celecoxib 
compared with either naproxen or ibuprofen: overall, cardiovascular adverse outcome rates were comparable but celecoxib was associated with a lower incidence of GI side effects ${ }^{69}$. This suggests that when really necessary celecoxib (in a dose up to $200 \mathrm{mg}$ daily) plus a full-dose PPI should not be withheld from patients requiring treatment after an NSAID-induced bleed.

PPI co-treatment would be usual after a PUB, and primary prevention of PUB in higher-risk patients taking anticoagulants is usually advocated by some but not all guidelines ${ }^{51,70-73}$. Surprisingly, there are little data to specifically support this practice; one recent study showed that omeprazole co-treatment reduced rebleeding in warfarin-treated patients, although this effect was significant only in those also taking anti-platelet drugs or NSAIDs ${ }^{74}$. A further observational study showed that concurrent use of PPIs or H2-receptor antagonists were both associated with a reduced risk of acute upper GI bleeding and this effect was most marked in those with a history of peptic ulcer disease $^{75}$. Therefore, despite the relative lack of evidence, co-prescription of gastroprotection with anticoagulant therapy would seem to be indicated in secondary prevention; for primary prevention, a case- and risk-based approach seems sensible pending further data. Those with highest risk of bleeding are most likely to gain from the use of acid suppression.

The rate of GI bleeding with DOACs compared with VKAs remains controversial. Whilst overall bleeding rates at all sites with DOACs do seem to be lower, this is mainly driven by a reduction in cerebral bleeding and the rate of GI bleeding may actually be increased but certainly does not seem convincingly lower. Several studies have shown either a higher rate of GI bleeding with DOACs or equivalent rates to $\mathrm{VKAs}^{76-79}$. The increased GI bleeding risk of DOACs seems especially marked in the most elderly (older than 76 years).

This effect on GI bleeding may be expected, as most of the DOACs are taken as active drugs (in contrast to VKAs) and relatively higher levels and local anticoagulant effects may be seen at the level of the GI mucosa. The choice of which anticoagulant (if any) to reintroduce after a PUB currently needs to be made on an individual basis, taking into account underlying risks and comorbidity, availability of antidotes, and patient preferences. It is clear that scoring systems for thrombotic risks in atrial fibrillation ( $\mathrm{CHADS}_{2}$-Vasc) and bleeding risk (HAS-BLED) can give important guidance on the relative risks of these important outcomes $^{80}$; however, there are no data specifically related to how using these scores prospectively to inform management decisions influences outcomes.

Studies from disparate geographical regions have shown an important increase in apparently idiopathic peptic ulcers as the cause of upper GI bleeding. Although this was initially reported in the Far East, studies from the UK and Europe have provided support, and these ulcers can contribute up to $40 \%$ of ulcers in some series and an even higher proportion of bleeding peptic ulcers occurring in hospital inpatients ${ }^{81-84}$. Though labelled idiopathic, they are typically seen in a more elderly population with significant comorbidity and may represent a marker of systemic vascular pathology. The importance of recognising this group lies not only in allowing secondary preventative management of PUB by cause (H. pylori, drug, idiopathic) but also in appreciating that this group is associated with not only a significantly higher risk of rebleeding compared with other causes (up to $42 \%$ at 7 years) but also much higher all-cause mortality (presumably due to the associated comorbidity; $87 \%$ mortality at 7 years ${ }^{85}$ ). Although continued acid suppression with a PPI is the logical intervention for this idiopathic ulcer group, one important study (albeit observational and not randomised) showed that acid suppression did not alter rebleeding or mortality in this group ${ }^{86}$. Other approaches, perhaps with alternative mucosal protectant agents such as misoprostol, would seem to be warranted.

\section{Conclusions}

Acute PUB remains an important clinical problem, but the management continues to be refined. Important recent developments that can be incorporated into practice include the confirmation of the usefulness of the GBS in determining the lowest-risk patients, who may be safely managed as outpatients. The GBS is most useful for predicting the need for intervention, but another score-either the Rockall or the AIM65 score-should also be assessed as a predictor of mortality to aid assessment of outcomes.

A restrictive transfusion threshold with a trigger of $70 \mathrm{~g} / \mathrm{l}$ and a target of $70-90 \mathrm{~g} / \mathrm{l}$ is appropriate for most patients, although transfusion triggers need to be interpreted within the context of resuscitation of the individual patient. Pre-endoscopy erythromycin is probably underused, and recent evidence supports wider use to improve endoscopic views. The addition of high-dose oral esomeprazole after initial proton pump therapy in high-risk cases (Rockall scores of 6 and above) seems to have an additional benefit in reducing rebleeding. For endoscopic treatment, the haemostatic powders and over-the-scope clips are useful tools when standard modalities are ineffective or impractical. The new Doppler equipment and disposable endoscopic Doppler probe appear to be extremely promising in more accurately predicting ulcer rebleeding and the success of endoscopic therapy and are likely to be widely used if further studies are confirmatory.

Strategies to manage the bleeding episode and prevent rebleeding need to include the management of comorbidities and risks and at present must include the management of bleeding associated with all anti-thrombotic agents, but particularly the DOACs. Specific antidotes are being developed and are just entering the clinical arena. Recent data suggest that the cardiovascular risk of celecoxib is not excessive compared with standard NSAIDs, and when used appropriately, celecoxib should once again be a useful tool in the primary and secondary prevention of PUB. Non-H. pylori, non-NSAID ulcers are becoming an increasing problem with a poor prognosis, and further studies are urgently required to define the safest and most effective management.

\section{Competing interests}

The author declares that he has no competing interests.

\section{Grant information}

The author(s) declared that no grants were involved in supporting this work. 
1. Crooks CJ, West J, Card TR: Upper gastrointestinal haemorrhage and deprivation: a nationwide cohort study of health inequality in hospital admissions. Gut. 2012; 61(4): 514-20.

PubMed Abstract | Publisher Full Text | Free Full Text

2. Hearnshaw SA, Logan RF, Lowe D, et al.: Acute upper gastrointestinal bleeding in the UK: patient characteristics, diagnoses and outcomes in the 2007 UK audit. Gut. 2011; 60(10): 1327-35.

PubMed Abstract | Publisher Full Text

3. Time to get control. London. NCEPOD. 2015. Reference Source

4. Barkun AN, Bardou M, Kuipers EJ, et al: International consensus recommendations on the management of patients with nonvariceal upper gastrointestinal bleeding. Ann Intern Med. 2010; 152(2): 101-13. PubMed Abstract | Publisher Full Text

5. F Gralnek IM, Dumonceau JM, Kuipers EJ, et al.: Diagnosis and management of nonvariceal upper gastrointestinal hemorrhage: European Society of Gastrointestinal Endoscopy (ESGE) Guideline. Endoscopy. 2015; 47(10): a1-46. PubMed Abstract | Publisher Full Text | F1000 Recommendation

6. F Villanueva C, Colomo A, Bosch A, et al:: Transfusion strategies for acute upper gastrointestinal bleeding. $N$ Engl J Med. 2013; 368(1): 11-21. PubMed Abstract | Publisher Full Text | F1000 Recommendation

7. Holst LB, Petersen MW, Haase N, et al:: Restrictive versus liberal transfusion strategy for red blood cell transfusion: systematic review of randomised trials with meta-analysis and trial sequential analysis. BMJ. 2015; 350: h1354. PubMed Abstract | Publisher Full Text | Free Full Text

8. F Holst LB: Benefits and harms of red blood cell transfusions in patients with septic shock in the intensive care unit. Dan Med J. 2016; 63(2): pii: B5209. PubMed Abstract | F1000 Recommendation

9. Jensen DM, Markovic D, Jensen ME, et al.: $\mathbf{7 8 4}$ Red Cell Transfusions Do Not Increase 30 Day Mortality Rates for Unselected Patients With Severe UGI Hemorrhage. Gastroenterology. 2015; 148(4 supplement 1): S-154, [Abstract]. Publisher Full Text

10. Wang J, Bao YX, Bai M, et al:: Restrictive vs liberal transfusion for upper gastrointestinal bleeding: a meta-analysis of randomized controlled trials. World J Gastroenterol. 2013; 19(40): 6919-27. PubMed Abstract | Publisher Full Text | Free Full Text

11. F Odutayo A, Desborough MJ, Trivella M, et al:: Restrictive versus liberal blood transfusion for gastrointestinal bleeding: a systematic review and metaanalysis of randomised controlled trials. Lancet Gastroenterol Hepatol. 2017; 2(5): 354-60.

PubMed Abstract | Publisher Full Text | F1000 Recommendation

12. Beales IL: Recent advances in peptic ulcer bleeding. F1000 Med Rep. 2009; 1: pii: 44.

PubMed Abstract | Publisher Full Text | Free Full Text

13. F Mokhtare M, Bozorgi V, Agah S, et al:: Comparison of Glasgow-Blatchford score and full Rockall score systems to predict clinical outcomes in patients with upper gastrointestinal bleeding. Clin Exp Gastroenterol. 2016; 9: 337-43. PubMed Abstract | Publisher Full Text | Free Full Text | F1000 Recommendation

14. Bryant RV, Kuo P, Williamson K, et al.: Performance of the Glasgow-Blatchford score in predicting clinical outcomes and intervention in hospitalized patients with upper GI bleeding. Gastrointest Endosc. 2013; 78(4): 576-83. PubMed Abstract | Publisher Full Text

15. F Stanley AJ, Laine L, Dalton HR, et al:: Comparison of risk scoring systems for patients presenting with upper gastrointestinal bleeding: international multicentre prospective study. BMJ. 2017; 356: i6432. PubMed Abstract | Publisher Full Text | Free Full Text | F1000 Recommendation

16. F Palmer AJ, Moroni F, Mcleish S, et al:: Risk assessment in acute nonvariceal upper GI bleeding: The AIMS65 score in comparison with the Glasgow-Blatchford score in a Scottish population. Frontline Gastroenterol. 2016; 7(2): 90-6.

PubMed Abstract | Publisher Full Text | Free Full Text | F1000 Recommendation

17. $\mathrm{F}$ lino $\mathrm{C}, \mathrm{Mikami} \mathrm{T}$, Igarashi $\mathrm{T}$, et al.: Evaluation of scoring models for identifying the need for therapeutic intervention of upper gastrointestinal bleeding: A new prediction score model for Japanese patients. Dig Endosc. 2016; 28(7): 714-21.

PubMed Abstract | Publisher Full Text | F1000 Recommendation

18. Schacher GM, Lesbros-Pantoflickova D, Ortner MA, et al:: Is early endoscopy in the emergency room beneficial in patients with bleeding peptic ulcer? A "fortuitously controlled" study. Endoscopy. 2005; 37(4): 324-8. PubMed Abstract | Publisher Full Text

19. Tai CM, Huang SP, Wang HP, et al:: High-risk ED patients with nonvariceal upper gastrointestinal hemorrhage undergoing emergency or urgent endoscopy: a retrospective analysis. Am J Emerg Med. 2007; 25(3): 273-8. PubMed Abstract | Publisher Full Text

20. Lim LG, Ho KY, Chan YH, et al:: Urgent endoscopy is associated with lower mortality in high-risk but not low-risk nonvariceal upper gastrointestinal bleeding. Endoscopy. 2011; 43(4): 300-6. PubMed Abstract | Publisher Full Text
21. Cheng DW, Lu YW, Teller T, et al:: A modified Glasgow Blatchford Score improves risk stratification in upper gastrointestinal bleed: a prospective comparison of scoring systems. Aliment Pharmacol Ther. 2012; 36(8): 782-9. PubMed Abstract | Publisher Full Text

22. Fullarton GM, Murray WR: Prediction of rebleeding in peptic ulcers by visual stigmata and endoscopic Doppler ultrasound criteria. Endoscopy. 1990; 22(2): 68-71.

PubMed Abstract | Publisher Full Text

23. F Jensen DM, Ohning GV, Kovacs TO, et al:: Doppler endoscopic probe as a guide to risk stratification and definitive hemostasis of peptic ulcer bleeding Gastrointest Endosc. 2016; 83(1): 129-36.

PubMed Abstract | Publisher Full Text | Free Full Text | F1000 Recommendation

24. F Jensen DM, Kovacs TOG, Ohning GV, et al:: Doppler Endoscopic Probe Monitoring of Blood Flow Improves Risk Stratification and Outcomes of Patients With Severe Nonvariceal Upper Gastrointestinal Hemorrhage. Gastroenterology. 2017; 152(6): 1310-1318.e1.

PubMed Abstract | Publisher Full Text | F1000 Recommendation

25. F Jensen DM, Eklund S, Persson T, et al:: Reassessment of Rebleeding Risk of Forrest IB (Oozing) Peptic Ulcer Bleeding in a Large International Randomized Trial. Am J Gastroenterol. 2017; 112(3): 441-6. PubMed Abstract | Publisher Full Text | F1000 Recommendation

26. F Honegger C, Valli PV, Wiegand N, et al.: Establishment of Over-The-Scope Clips (OTSC $($ ) in daily endoscopic routine. United European Gastroenterol J. 2017; 5(2): 247-54

PubMed Abstract | Publisher Full Text | Free Full Text | F1000 Recommendation

27. Chan SM, Chiu PW, Teoh AY, et al.: Use of the Over-The-Scope Clip for treatment of refractory upper gastrointestinal bleeding: a case series. Endoscopy. 2014; 46(5): 428-31.

PubMed Abstract | Publisher Full Text

28. F Manno M, Mangiafico S, Caruso A, et al.: First-line endoscopic treatment with OTSC in patients with high-risk non-variceal upper gastrointestinal bleeding: preliminary experience in $\mathbf{4 0}$ cases. Surg Endosc. 2016; 30(5): 2026-9. PubMed Abstract | Publisher Full Text | F1000 Recommendation

29. F Changela $\mathrm{K}$, Papafragkakis $\mathrm{H}$, Ofori $\mathrm{E}$, et al:: Hemostatic powder spray: a new method for managing gastrointestinal bleeding. Therap Adv Gastroenterol. 2015; 8(3): 125-35

PubMed Abstract | Publisher Full Text | Free Full Text | F1000 Recommendation

30. Leontiadis GI, Sharma VK, Howden CW: Proton pump inhibitor therapy for peptic ulcer bleeding: Cochrane collaboration meta-analysis of randomized controlled trials. Mayo Clin Proc. 2007; 82(3): 286-96.

PubMed Abstract | Publisher Full Text

31. F Tsoi KK, Hirai HW, Sung JJ: Meta-analysis: comparison of oral vs. intravenous proton pump inhibitors in patients with peptic ulcer bleeding. Aliment Pharmacol Ther. 2013; 38(7): 721-8. PubMed Abstract | Publisher Full Text | F1000 Recommendation

32. F Neumann I, Letelier LM, Rada G, et al:: Comparison of different regimens of proton pump inhibitors for acute peptic ulcer bleeding. Cochrane Database Syst Rev. 2013; (6): CD007999.

PubMed Abstract | Publisher Full Text | F1000 Recommendation

33. Cheng $\mathrm{HC}$, Wu CT, Chang WL, et al:: Double oral esomeprazole after a 3-day intravenous esomeprazole infusion reduces recurrent peptic ulcer bleeding in high-risk patients: a randomised controlled study. Gut. 2014; 63(12): 1864-72. PubMed Abstract | Publisher Full Text

34. Theivanayagam S, Lim RG, Cobell WJ, et al:: Administration of erythromycin before endoscopy in upper gastrointestinal bleeding: a meta-analysis of randomized controlled trials. Saudi J Gastroenterol. 2013; 19(5): 205-10. PubMed Abstract | Publisher Full Text | Free Full Text

35. Szary NM, Gupta R, Choudhary A, et al.: Erythromycin prior to endoscopy in acute upper gastrointestinal bleeding: a meta-analysis. Scand J Gastroenterol. 2011; 46(7-8): 920-4.

PubMed Abstract | Publisher Full Text

36. Daram SR, Garretson R: Erythromycin is preferable to metoclopramide as a prokinetic in acute upper GI bleeding. Gastrointest Endosc. 2011; 74(1): 234; author reply 234-5.

PubMed Abstract | Publisher Full Text

37. F Glund S, Stangier J, Schmohl M, et al:: Safety, tolerability, and efficacy of idarucizumab for the reversal of the anticoagulant effect of dabigatran in healthy male volunteers: a randomised, placebo-controlled, double-blind phase 1 trial. Lancet. 2015; 386(9994): 680-90. PubMed Abstract | Publisher Full Text | F1000 Recommendation

38. F Pollack CV Jr, Reilly PA, Eikelboom J, et al:: Idarucizumab for Dabigatran Reversal. N Engl J Med. 2015; 373(6): 511-20.

PubMed Abstract | Publisher Full Text | F1000 Recommendation

39. Bennett C, Klingenberg SL, Langholz E, et al:: Tranexamic acid for upper gastrointestinal bleeding. Cochrane Database Syst Rev. 2014; (11): CD006640. PubMed Abstract | Publisher Full Text

40. Roberts I, Coats T, Edwards P, et al:: HALT-IT--tranexamic acid for the treatment 
of gastrointestinal bleeding: study protocol for a randomised controlled trial. Trials. 2014; 15: 450.

PubMed Abstract | Publisher Full Text | Free Full Text

41. F Veitch AM, Vanbiervliet G, Gershlick AH, et al.: Endoscopy in patients on antiplatelet or anticoagulant therapy, including direct oral anticoagulants: British Society of Gastroenterology (BSG) and European Society of Gastrointestinal Endoscopy (ESGE) guidelines. Endoscopy. 2016; 48(4): c1. PubMed Abstract | Publisher Full Text | F1000 Recommendation

42. F Schultz NH, Tran HTT, Bjørnsen S, et al.: The reversal effect of prothrombin complex concentrate (PCC), activated PCC and recombinant activated factor VII against anticoagulation of Xa inhibitor. Thromb J. 2017; 15: 6 . PubMed Abstract | Publisher Full Text | Free Full Text | F1000 Recommendation

43. F Connolly SJ, Milling TJ Jr, Eikelboom JW, et al: Andexanet Alfa for Acute Major Bleeding Associated with Factor Xa Inhibitors. N Engl J Med. 2016; 375(12): 1131-41.

PubMed Abstract | Publisher Full Text | Free Full Text | F1000 Recommendation

44. Bager $P$, Dahlerup JF: Randomised clinical trial: oral vs. intravenous iron after upper gastrointestinal haemorrhage--a placebo-controlled study. Aliment Pharmacol Ther. 2014; 39(2): 176-87.

PubMed Abstract | Publisher Full Text

45. Wong TC, Wong K, Chiu PW, et al.: A comparison of angiographic embolization with surgery after failed endoscopic hemostasis to bleeding peptic ulcers. Gastrointest Endosc. 2011; 73(5): 900-8.

PubMed Abstract | Publisher Full Text

46. Katano T, Mizoshita T, Senoo K, et al:: The efficacy of transcatheter arterial embolization as the first-choice treatment after failure of endoscopic hemostasis and endoscopic treatment resistance factors. Dig Endosc. 2012; 24(5): 364-9.

PubMed Abstract | Publisher Full Text

47. Lee HH, Park JM, Chun HJ, et al.: Transcatheter arterial embolization for endoscopically unmanageable non-variceal upper gastrointestinal bleeding Scand J Gastroenterol. 2015; 50(7): 809-15.

PubMed Abstract | Publisher Full Text

48. Kyaw M, Tse $Y$, Ang D, et al.: Embolization versus surgery for peptic ulcer bleeding after failed endoscopic hemostasis: a meta-analysis. Endosc Int Open. 2014; 2(1): E6-E14.

PubMed Abstract | Publisher Full Text | Free Full Text

49. F Griffiths EA, McDonald CR, Bryant RV, et al:: Retrospective analysis of surgery and trans-arterial embolization for major non-variceal uppe gastrointestinal bleeding. ANZ J Surg. 2016; 86(5): 381-5.

PubMed Abstract | Publisher Full Text | F1000 Recommendation

50. Gisbert JP, Abraira V: Accuracy of Helicobacter pylori diagnostic tests in patients with bleeding peptic ulcer: a systematic review and meta-analysis. $A m$ J Gastroenterol. 2006; 101(4): 848-63. PubMed Abstract | Publisher Full Tex

51. Brooks J, Warburton R, Beales IL: Prevention of upper gastrointestinal haemorrhage: current controversies and clinical guidance. Ther Adv Chronic Dis. 2013; 4(5): 206-22.

PubMed Abstract | Publisher Full Text | Free Full Text

52. $\mathrm{F}$ Malfertheiner P, Megraud F, O'Morain CA, et al:: Management of Helicobacter pylori infection-the Maastricht V/Florence Consensus Report. Gut. 2017; 66(1): 6-30.

PubMed Abstract | Publisher Full Text | F1000 Recommendation

53. Sánchez-Delgado J, Gené E, Suárez D, et al:: Has $H$. pylori prevalence in bleeding peptic ulcer been underestimated? A meta-regression. Am J Gastroenterol. 2011; 106(3): 398-405.

PubMed Abstract | Publisher Full Tex

54. F Sung JJ, Lau JY, Ching JY, et al.: Continuation of low-dose aspirin therapy in peptic ulcer bleeding: a randomized trial. Ann Intern Med. 2010; 152(1): 1-9. PubMed Abstract | Publisher Full Text | F1000 Recommendation

55. F Derogar M, Sandblom G, Lundell L, et al.: Discontinuation of low-dose aspirin therapy after peptic ulcer bleeding increases risk of death and acute cardiovascular events. Clin Gastroenterol Hepatol. 2013; 11(1): 38-42. PubMed Abstract | Publisher Full Text | F1000 Recommendation

56. Lai KC, Chu KM, Hui WM, et al.: Esomeprazole with aspirin versus clopidogrel for prevention of recurrent gastrointestinal ulcer complications. Clin Gastroenterol Hepatol. 2006; 4(7): 860-5. PubMed Abstract | Publisher Full Text

57. F Wallentin L, Becker RC, Budaj A, et al.: Ticagrelor versus clopidogrel in patients with acute coronary syndromes. N Engl J Med. 2009; 361(11): 1045-57. PubMed Abstract | Publisher Full Text | F1000 Recommendation

58. $F$ Xin YG, Zhang HS, Li YZ, et al.: Efficacy and safety of ticagrelor versus clopidogrel with different dosage in high-risk patients with acute coronary syndrome. Int J Cardiol. 2017; 228: 275-9.

PubMed Abstract | Publisher Full Text | F1000 Recommendation

59. F Bhatt DL, Cryer BL, Contant CF, et al:: Clopidogrel with or without omeprazole in coronary artery disease. N Engl J Med. 2010; 363(20): 1909-17. PubMed Abstract | Publisher Full Text | F1000 Recommendation

60. $\mathrm{Ng} \mathrm{FH}$, Wong BC, Wong SY, et al.: Clopidogrel plus omeprazole compared with aspirin plus omeprazole for aspirin-induced symptomatic peptic ulcers/ erosions with low to moderate bleeding/re-bleeding risk -- a single-blind, randomized controlled study. Aliment Pharmacol Ther. 2004; 19(3): 359-65. PubMed Abstract | Publisher Full Text

61. Hsiao FY, Tsai YW, Huang WF, et al:: A comparison of aspirin and clopidogrel with or without proton pump inhibitors for the secondary prevention of cardiovascular events in patients at high risk for gastrointestinal bleeding. Clin Ther. 2009; 31(9): 2038-47.

PubMed Abstract | Publisher Full Text

62. Casado Arroyo R, Polo-Tomas M, Roncalés MP, et al.: Lower Gl bleeding is more common than upper among patients on dual antiplatelet therapy: long-term follow-up of a cohort of patients commonly using PPI co-therapy. Heart. 2012; 98(9): 718-23

PubMed Abstract | Publisher Full Text

63. F Chan FK, Kyaw M, Tanigawa T, et al:: Similar Efficacy of ProtonPump Inhibitors vs H2-Receptor Antagonists in Reducing Risk of Upper Gastrointestinal Bleeding or Ulcers in High-Risk Users of Low-Dose Aspirin. Gastroenterology. 2017; 152(1): 105-110.e1.

PubMed Abstract | Publisher Full Text | F1000 Recommendation

64. $\mathrm{F}$ Ng FH, Wong SY, Lam KF, et al.: Famotidine is inferior to pantoprazole in preventing recurrence of aspirin-related peptic ulcers or erosions. Gastroenterology. 2010; 138(1): 82-8.

PubMed Abstract | Publisher Full Text | F1000 Recommendation

65. F Sengupta N, Feuerstein JD, Patwardhan VR, et al.: The risks of thromboembolism vs. recurrent gastrointestinal bleeding after interruption of systemic anticoagulation in hospitalized inpatients with gastrointestinal bleeding: a prospective study. Am J Gastroenterol. 2015; 110(2): 328-35. PubMed Abstract | Publisher Full Text | F1000 Recommendation

66. Staerk L, Lip GY, Olesen JB, et al:: Stroke and recurrent haemorrhage associated with antithrombotic treatment after gastrointestinal bleeding in patients with atrial fibrillation: nationwide cohort study. BMJ. 2015; 351: h5876. PubMed Abstract | Publisher Full Text | Free Full Text

67. Beales IL: Decisions on restarting anticoagulation should be made earlier after rebleeding. BMJ. 2016; 532: i248. PubMed Abstract | Publisher Full Text

68. F Scott MJ, Veitch A, Thachil J: Reintroduction of anti-thrombotic therapy after a gastrointestinal haemorrhage: if and when? Br J Haematol. 2017; 177(2): 185-97.

PubMed Abstract | Publisher Full Text | F1000 Recommendation

69. F Nissen SE, Yeomans ND, Solomon DH, et al:: Cardiovascular Safety of Celecoxib, Naproxen, or Ibuprofen for Arthritis. N Engl J Med. 2016; 375(26) 2519-29.

PubMed Abstract | Publisher Full Text | F1000 Recommendation

70. Ansell J, Hirsh J, Hylek E, et al:: Pharmacology and management of the vitamin $\mathrm{K}$ antagonists: American College of Chest Physicians Evidence-Based Clinical Practice Guidelines (8th Edition). Chest. 2008; 133(6 Suppl): 160S-198S. PubMed Abstract | Publisher Full Text

71. Schulman S, Beyth RJ, Kearon C, et al:: Hemorrhagic complications of anticoagulant and thrombolytic treatment: American College of Chest Physicians Evidence-Based Clinical Practice Guidelines (8th Edition). Chest. 2008; 133 (6 Suppl): 257S-298S.

PubMed Abstract | Publisher Full Text

72. Garcia DA, Witt DM, Hylek E, et al.: Delivery of optimized anticoagulant therapy: consensus statement from the Anticoagulation Forum. Ann Pharmacother. 2008; 42(7): 979-88.

PubMed Abstract | Publisher Full Text

73. January CT, Wann LS, Alpert JS, et al:: 2014 AHA/ACC/HRS guideline for the management of patients with atrial fibrillation: a report of the American College of Cardiology/American Heart Association Task Force on Practice Guidelines and the Heart Rhythm Society. J Am Coll Cardiol. 2014; 64(21): e1-76.

PubMed Abstract | Publisher Full Text

74. F Ray WA, Chung CP, Murray KT, et al:: Association of Proton Pump Inhibitors With Reduced Risk of Warfarin-Related Serious Upper Gastrointestinal Bleeding. Gastroenterology. 2016; 151(6): 1105-1112.e10. PubMed Abstract | Publisher Full Text | Free Full Text | F1000 Recommendation

75. Chan EW, Lau WC, Leung WK, et al.: Prevention of Dabigatran-Related Gastrointestinal Bleeding With Gastroprotective Agents: A Population-Based Study. Gastroenterology. 2015; 149(3): 586-95.e3.

PubMed Abstract | Publisher Full Text

76. F Sherwood MW, Nessel CC, Hellkamp AS, et al:: Gastrointestinal Bleeding in Patients With Atrial Fibrillation Treated With Rivaroxaban or Warfarin: ROCKET AF Trial. J Am Coll Cardiol. 2015; 66(21): 2271-81. PubMed Abstract | Publisher Full Text | F1000 Recommendation

77. F Ruff CT, Giugliano RP, Braunwald E, et al:: Comparison of the efficacy and safety of new oral anticoagulants with warfarin in patients with atria fibrillation: a meta-analysis of randomised trials. Lancet. 2014; 383(9921): 955-62.

PubMed Abstract | Publisher Full Text | F1000 Recommendation 
78. F Holster IL, Valkhoff VE, Kuipers EJ, et al.: New oral anticoagulants increase risk for gastrointestinal bleeding: a systematic review and meta-analysis. Gastroenterology. 2013; 145(1): 105-112.e15.

PubMed Abstract | Publisher Full Text | F1000 Recommendation

79. Abraham NS, Singh S, Alexander GC, et al:: Comparative risk of gastrointestina bleeding with dabigatran, rivaroxaban, and warfarin: population based cohort study. BMJ. 2015; 350: h1857.

PubMed Abstract | Publisher Full Text | Free Full Text

80. F Pisters R, Lane DA, Nieuwlaat R, et al:: A novel user-friendly score (HAS-BLED) to assess 1-year risk of major bleeding in patients with atrial fibrillation: the Euro Heart Survey. Chest. 2010; 138(5): 1093-100. PubMed Abstract | Publisher Full Text | F1000 Recommendation

81. Dore MP, Marras G, Rocchi C, et al:: Changing prevalence of Helicobacter pylor infection and peptic ulcer among dyspeptic Sardinian patients. Intern Emerg Med. 2015; 10(7): 787-94.

PubMed Abstract | Publisher Full Text

82. Kanno $\mathrm{T}$, lijima $\mathrm{K}, \mathrm{Abe} \mathrm{Y}$, et al.: A multicenter prospective study on the prevalence of Helicobacter pylori-negative and nonsteroidal anti-inflammatory drugs-negative idiopathic peptic ulcers in Japan. J Gastroenterol Hepatol. 2015;
30(5): 842-8.

PubMed Abstract | Publisher Full Text

83. Charpignon C, Lesgourgues B, Pariente A, et al: Peptic ulcer disease: one in five is related to neither Helicobacter pylori nor aspirin/NSAID intake. Aliment Pharmacol Ther. 2013; 38(8): 946-54.

PubMed Abstract | Publisher Full Text

84. Musumba C, Jorgensen A, Sutton L, et al:: The relative contribution of NSAIDs and Helicobacter pylori to the aetiology of endoscopically-diagnosed peptic ulcer disease: observations from a tertiary referral hospital in the UK between 2005 and 2010. Aliment Pharmacol Ther. 2012; 36(1): 48-56. PubMed Abstract | Publisher Full Text

85. $\mathrm{F}$ Wong GL, Wong VW, Chan $\mathrm{Y}$, et al:: High incidence of mortality and recurrent bleeding in patients with Helicobacter pylori-negative idiopathic bleeding ulcers. Gastroenterology. 2009; 137(2): 525-31. PubMed Abstract | Publisher Full Text | F1000 Recommendation

86. F Wong GL, Au KW, Lo AO, et al:: Gastroprotective therapy does not improve outcomes of patients with Helicobacter pylori-negative idiopathic bleeding ulcers. Clin Gastroenterol Hepatol. 2012; 10(10): 1124-9.

PubMed Abstract | Publisher Full Text | F1000 Recommendation 


\section{Open Peer Review}

\section{Current Peer Review Status:}

\section{Editorial Note on the Review Process}

Faculty Reviews are review articles written by the prestigious Members of Faculty Opinions. The articles are commissioned and peer reviewed before publication to ensure that the final, published version is comprehensive and accessible. The reviewers who approved the final version are listed with their names and affiliations.

\section{The reviewers who approved this article are:}

\section{Version 1}

\section{Grigorios I Leontiadis}

Department of Medicine, Division of Gastroenterology, McMaster University, Hamilton, Ontario, Canada

Competing Interests: No competing interests were disclosed.

\section{David M Jensen}

David Geffen School of Medicine at UCLA, Los Angeles, California, USA

Competing Interests: No competing interests were disclosed.

The benefits of publishing with F1000Research:

- Your article is published within days, with no editorial bias

- You can publish traditional articles, null/negative results, case reports, data notes and more

- The peer review process is transparent and collaborative

- Your article is indexed in PubMed after passing peer review

- Dedicated customer support at every stage

For pre-submission enquiries, contact research@f1000.com 